\title{
Double Trouble: Spontaneous Duodenal Hematoma of Pancreatic Origin
}

\author{
Luísa Martins Figueiredo David Valadas Horta Jorge A. Reis \\ Gastroenterology Department, Hospital Professor Doutor Fernando Fonseca, Amadora, Portugal
}

\section{Keywords}

Duodenal hematoma - Acute pancreatitis - Gastric outlet obstruction

\section{Duplo Problema: Hematoma Duodenal Espontâneo de Origem Pancreática}

\section{Palavras Chave}

Hematoma duodenal · Pancreatite aguda · Obstrução da saída gástrica

A 55-year-old alcohol-dependent man presented to the hospital for a 6-day history of epigastric pain radiating to the back, associated with nausea and uncontrollable vomiting. He denied any known coagulation disorder, recent abdominal trauma, or endoscopic/surgical intervention. Physical examination revealed scleral icterus, abdominal distention, and epigastric tenderness. Investigation identified hyperamylasemia (441 IU/L), high creatinine $(6.02 \mathrm{mg} / \mathrm{dL})$, and total serum bilirubin $(2.89$ $\mathrm{mg} / \mathrm{dL}$ ). Abdominal computed tomography (CT) performed without intravenous contrast enhancement showed duodenal distension with spontaneously hyper-

\section{KARGER}

E-Mail karger@karger.com www.karger.com/pig
(C) 2019 Sociedade Portuguesa de Gastrenterologia

Published by S. Karger AG, Basel

Karger

Open access

This article is licensed under the Creative Commons AttributionNonCommercial-NoDerivatives 4.0 International License (CC BYNC-ND) (http://www.karger.com/Services/OpenAccessLicense). Usage and distribution for commercial purposes as well as any distribution of modified material requires written permission. dense obstructive lesion in the descending duodenum and changes suggesting the presence of acute pancreatitis (Fig. 1). This was suggestive of an obstructive intramural duodenal hematoma (IDH) in the descending duodenum. A nasogastric decompression was performed, and the patient was kept on nil by mouth and treated with intravenous fluid hydration, parenteral nutrition, and proton pump inhibitor. The patient improved with remission of abdominal pain and vomiting as well as recovery of renal function. Three weeks later, abdominal magnetic resonance imaging demonstrated a marked reduction in the size of the IDH (Fig. 2).

Spontaneous IDHs of pancreatic origin are rare. IDH was first described by McLauchlan in 1838 [1, 2]. The reason why the duodenum is rarely involved in spontaneous intramural small bowel hematoma remains unclear. Since the duodenum is the shortest part of the small intestine and is fixed and compressed by surrounding extraluminal organs, a duodenal intramural hematoma may be more easily absorbed compared to those in the jejunum or ileum [3].

IDH usually occurs secondary to blunt abdominal injury, but spontaneous nontraumatic cases have been linked to coagulopathy, coagulating drugs, and endoscopic procedures $[1,2,4]$. However, there are many reports regarding the association of IHD with acute pancreatitis and pancreatic malignancy [2]. 


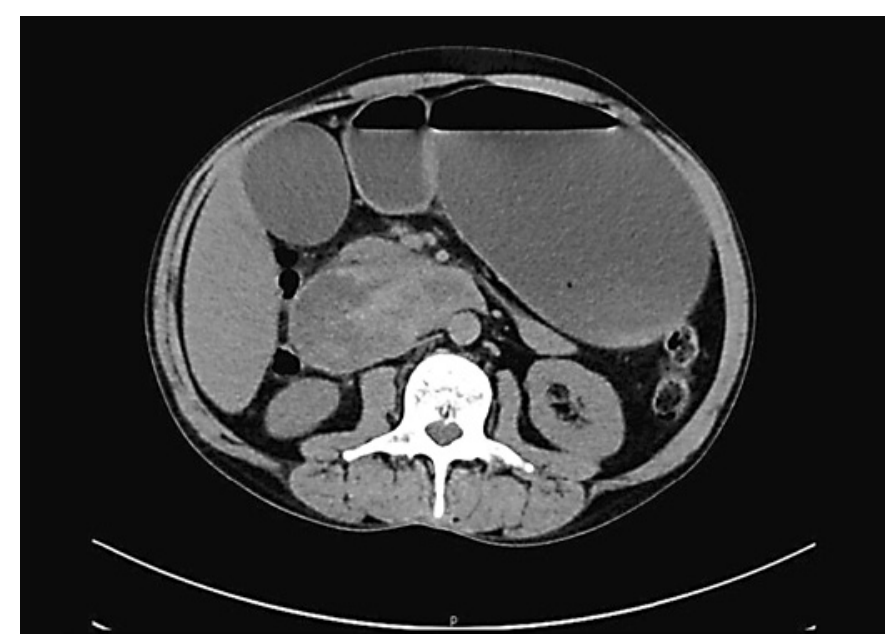

Fig. 1. Abdominal CT showing a spontaneous hyperdense obstructive lesion in the descending duodenum causing dilation of the duodenal cap.

In general, CT is the imaging choice for diagnosis of spontaneous intramural small bowel hematoma [2]. Reassessment of the status of the hematoma is generally recommended in 2 weeks following diagnosis and conservative management $[2,4]$. Conservative management constituted bowel rest, continuous nasogastric decompression, parenteral nutrition, blood transfusion, and correction of coagulopathy when needed. Surgical intervention is only indicated if there is significant intraluminal hemorrhage, bowel perforation, or an identifiable risk of ischemia $[2,4]$.

Both short-term and long-term outcomes are important in the absence of any other concurrent condition [4]. We presented a rare case of a giant IDH of pancreatic origin complicated with gastric outlet obstruction solved with conservative therapy.

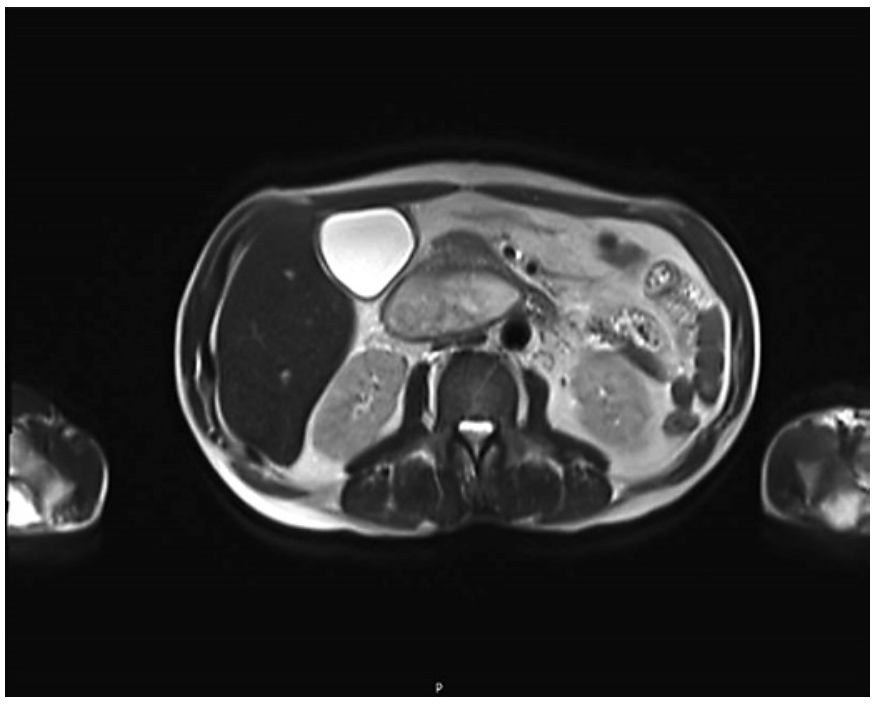

Fig. 2. Abdominal magnetic resonance showing a marked reduction in the size of the duodenal hematoma.

\section{Statement of Ethics}

The authors have no ethical conflicts to disclose.

\section{Disclosure Statement}

The authors have no conflicts of interest to declare.

\section{Author Contributions}

All listed authors contributed meaningfully to the study, as follows: Luísa Martins Figueiredo drafted the article; David Horta and Jorge Reis critically revised the article; and all authors approved the final version for publication. All authors agreed to be accountable for all aspects of the work in ensuring that questions related to the accuracy or integrity of any part of the work are appropriately investigated and resolved.

\section{References}

Spontaneous Duodenal Hematoma
1 Eurboonyanun C, Somsap K, Ruangwannasak S, et al. Spontaneous intramural duodenal hematoma: pancreatitis, obstructive jaundice, and upper intestinal obstruction. Case Rep Surg. 2016;2016:5321081.

2 Eichele DD, Ross M, Tang P, Hutchins GF, Mailliard M. Spontaneous intramural duodenal hematoma in type $2 \mathrm{~B}$ von Willebrand disease. World J Gastroenterol. 2013 Nov;19(41): 7205-8.
3 Kang EA, Han SJ, Chun J, Lee HJ, Chung H, Im JP, et al. Clinical features and outcomes in spontaneous intramural small bowel hematoma: cohort study and literature review. Intest Res. 2018. https://doi.org/10.5217/ ir.2018.00085.

4 Bayraktar A, Ercan LD, Bakkaloğlu H, Gök AF, İlhan M, Aydın AE. Duodenal intramural hematoma due to early postoperative anticoagulant treatment after a renal transplant: A case report. Ulus Travma Acil Cerrahi Derg. 2018 Nov;24(6):594-6. 